\title{
FRAUD IN DOCUMENTARY LETTERS OF CREDIT; A COMPARATIVE STUDY OF EXCISING INTERNATIONAL LEGAL FRAMEWORKS
}

\author{
Hamed Alavi \\ Tallinn School of Law, Tallinn University of Technology \\ Faculty of Law, Universitat Autònoma de Barcelona, Spain
}

\begin{abstract}
Documentary letters of credit are among most popular trade finance instruments used in international business. Despite the fact that main purpose derived from application of documentary letters of credit is to reduce the risk of trade, their mere documentary nature makes them vulnerable to the problem fraud. There is a huge interest among legal scholars and academicians to analyse the nature of fraud in documentary letters of credit due to its important financial effect on smooth process of international trade and also diversified approach of different legal systems to this particular problem. However, majority of conducted studies are limited to most popular legal systems including British and American law. Need for studying the LC fraud in a comprehensive comparative manner among existing international legal frameworks is well noticed for long time. Due to their international nature, LC operation is subjected to substantial number of legal frameworks which most of them are either taking a silent position towards problem of fraud or do not show uniform approach to the it. In this paper, author tries to study different sources of law in documentary letters of credit and their approach to the problem of fraud in a comparative manner. The main research question is what would be the position of fraud rule in applicable legal frameworks to the international LC operation and how do they approach the problem of fraud committed by beneficiary in documentary letters of credit? For this purpose, paper is divided into four main parts: After the introduction, second part will discuss the sources of law applicable to international LC transaction. Third section will analyse the legal nature of fraud in LC transaction. Fourth section will scrutinize the legal approach of different legal frameworks to fraud in documentary letters of credit and finally, the last section will sum up the discussion with concluding remarks.
\end{abstract}

Keywords: letters of credit, fraud

\section{INTRODUCTION}

Documentary letters of credit are among most popular trade finance instruments used in international trade. They are also known as "Life bold of international commerce". ${ }^{1}$ In the simple documentary letters of credit transaction, an importer-buyer approaches a bank of good reputation to open an irrevocable letter of credit in favour of exporter to cover the cost of goods or services covered in the underlying contract between parties. In this way, risk of payment from buyer will be transferred to a bank with much stronger financial standing. ${ }^{2}$ The credit will be advised to the

Harbottle (RD) (Mercantile) Ltd v National Westminster Bank Ltd [1978] 1 QB 146.

ALAVI, H.: Documentary Letters of Credit, Legal Nature and Sources of Law. In: Journal of legal studies, 2016, 17, 31, pp. 106-121. 
exporter and in case of his agreement with terms and conditions of the credit, it will be issued in his favour. Exporter will ship the goods to importer and present complying documents to terms and conditions of the credit to bank. The bank will honour seller's presentation after examination of documents presented by seller and making sure about their strict compliance with the credit. As a result, it is possible to mention that three main parties are involved in operation of commercial documentary letters of credit: Importer applicant, exporter and issuing bank. However, due to long distance between buyer and seller in international commercial transaction, other parties will eventually become involved in operation of documentary letters of credit. Such parties can play the role of advising bank, confirming bank, nominated bank and reimbursing bank. ${ }^{3}$ The development of law and practice of documentary letters of credit has been subject to customs of international trade as evolved in the course of time. ${ }^{4}$ Despite the fact that main purpose derived from application of documentary letters of credit in practice of international trade finance is to reduce the risk of trade, their mere documentary nature makes them vulnerable to the problem of fraud. ${ }^{5}$ This is evident from "a huge volume of case law concerning the issue of fraud has grown up. Legal writing on this topic is no less voluminous."' There is a huge interest among legal scholars and academicians to analyse the nature of fraud in documentary letters of credit due to its important financial effect on smooth process of international trade and also diversified approach of different legal systems to this particular problem. Fraud in documentary letters of credit is even considered as "the most controversial and confused area" because it "goes to the heart" of letter of credit operation. ${ }^{8}$ Situation will be even more complicated when it becomes clear that due to international nature of LC operation, they are subjected to substantial number of legal frameworks where most of them are either taking a silent position towards or do not show uniform approach to the same problem. United States of America is the only country which has statutory law which recognizes the fraud in documentary letters of credit. Article 5-109 of the revised Uniform Commercial Code provides a detailed legal position of LC fraud in American legal system. In England, LC fraud is subject to principles of common law system embodied in number body of case law on the subject matter. Other existing legal frameworks applicable to international operation of documentary letters of credit have more international nature and were introduced by International Chamber of Commerce or UNCITRAL. ICC has introduced Uniform Customs and Practices for Documentary Letters of Credit (UCP), Uniform Rules for Demand Guarantees (URDG), Uniform Rules for Contract Guarantees (URCG), International Standby Practices (ISP 98). UNCITRAL has introduced United Nations Convention on Independent Guarantees and Standby Letters of Credit (the Convention) on 1995. ${ }^{9}$

3 ALAVI, H.: Illegality as an Exception to Principle of Autonomy in Documentary Letters of Credit; A Comparative Approach. In: Korea University Law Review, 2016, 20, pp. 3-23.

4 KOZLCHYK, B., Letters of Credit. In: Int'l Encyclopaedia of Comparative Law, 1979, 10.

5 ALAVI, H.: Autonomy Principle and Fraud Exception in Documentary Letters of Credit, a Comparative Study between United States and England. In: International and Comparative Law Review, 2015, 15, 2, p. 45.

6 BERTRAMS, R.: Bank Guarantees in International Trade. 3d. ed. The Hague: Kluwer Law International, 2004, p. 335.

7 BUCKLEY, R.P. - GAO, X.: The Development of the Fraud Rule in Letter of Credit Law: The Journey so Far and the Road Ahead. In: University of Pennsylvania Journal of Economic Law, 2002, 23, p. 663.

8 BUCKLEY, R.P. - GAO, X.: Comparative Analysis of the Standard of Fraud Required under the Fraud Rule in Letter of Credit Law. In: Duke J. Comp. \& Int'l L., 2003, 13, p. 293.

9 United Nations Convention on Independent Guarantees and Stand-by Letters of Credit art. 5, Dec. 11, 1995, A/ RES/50/48. Available at http://www.uncitral.org/pdf/english/texts/ payments/guarantees/guarantees.pdf [ the Convention]. 
In this paper, author tries to study different sources of law in documentary letters of credit and their approach to the problem of fraud in a comparative manner. The main research question which current paper is trying to answer is what would be the position of fraud rule in applicable legal frameworks to the international LC operation and how do they approach the problem of documentary fraud in documentary letters of credit?

For this purpose, paper is divided into four main parts: After the introduction, second part will discuss the sources of law applicable to international LC transaction. Third section will analyse the legal nature of fraud in LC transaction. Fourth section will scrutinize the legal approach of different legal frameworks to fraud in documentary letters of credit and finally, the last section will sum up the discussion with concluding remarks.

\section{SOURCES OF LETTER OF CREDIT LAW}

In the course of history, development of law and regulations of the Documentary Letter of Credit was based on custom. However, in modern times International Chamber of commerce has provided the major source of law for documentary letters by assuming the responsibility for codification of relevant customs and usage under Unified Custom and Practices for Documentary Credits (UCP). Additionally, International Chamber of Commerce has introduced other regulations including eUCP, Uniform Rules of Contract Guarantees, Uniform Rules for Demand Guarantees, ISP98, which is International Standby Practices for Independent Guarantees and Standby Documentary Credits. United Nations Conference for International Trade Law also individually took the initiative to prepare universal regulations for Independent Guarantees and Standby Letters of Credits which is known as UNCITRAL Convention. Despite existence of many international frameworks for regulation of documentary credits, this issue has been addressed in few national law systems. Among Civil Law countries only Colombia, El Salvador, Greece, Guatemala, Honduras, Lebanon, Mexico, and Syria have statutory rules on the letter of credit; and, the only country in the common law system is the United States. In other Common Law Countries including England, legal issues of documentary credits are subjected to case law.

The main focus of current paper in this section will be study of different International legal sources for documentary credits, and also the answer of common law system to the question of legal framework for documentary credits.

\section{PRINCIPLE OF AUTONOMY AND FRAUD RULE}

\subsection{Principle of Autonomy}

Alongside with principle of strict compliance in operation of letters of credit and cornerstone of current article is Principle of Autonomy. Independence principle has been recognised and appreciated in national and international law. ${ }^{10}$ The principle of autonomy of letters of credit has been consid-

10 Article 4 UCP 600; Article 2(b) URDG; Articles 2 and 3 UNCITRAL-Convention; sections 5-10 (1)(a), 5-114 (1) and 5 5-103(d) UCC. 
ered as "the engine behind the letter of credit", 11 and "cornerstone of the commercial validity of the letters of credit". ${ }^{12}$ Principle of Independence has been clearly mentioned in article 4 of UCP 600:

«Article 4 Credits v. Contracts

a. A credit by its nature is a separate transaction from the sale or other contract on which it may be based. Banks are in no way concerned with or bound by such contract, even if any reference whatsoever to it is included in the credit. Consequently, the undertaking of a bank to honour, to negotiate or to fulfil any other obligation under the credit is not subject to claims or defences by the applicant resulting from its relationships with the issuing bank or the beneficiary."

According to Article 4 of the UCP 600 by referring to principle of independence, the beneficiary exporter receives the guarantee that he will be paid after tendering the complying presentation of documents to the issuing bank. Neither bank nor the account party will be able to withhold payment with relevant arguments to the quality of delivered goods or other issues related to performance of underlying contract. Therefore, even in cases of conflict on performance of underlying contract account party and issuing bank have no other choice rather than paying beneficiary upon presentation of complying documents and seek remedy by suing him for the breach of underlying contract. As a result, Autonomy Principle has been considered a means of promoting international trade by following the logic of "pay first, argue later". ${ }^{13}$

The autonomy principle also has been considered as the foundation for smooth operation of letter of credits by many scholars. ${ }^{14}$

In order to completely address the essence of autonomy principle, article 5 of UCP 600 specifies: "banks deal with documents and not with goods, services or performance to which the documents may relate." ${ }^{15}$

\subsubsection{Principle of Autonomy and Common Law Position}

The principle of autonomy has been recognized in many common law cases. ${ }^{16}$ Particularly, the importance of autonomy principle has been recognized by Lord Diplock in United City merchants (Investment) Ltd $v$ Royal Bank of Canada. ${ }^{17}$

'The whole commercial purpose for which the system of confirmed irrevocable documentary credits has been developed in international trade is to give to the seller an assured right to be paid before he parts with control of the goods that does not permit of any dispute with the buyer as to the performance of the contract of sale being used as a ground for non-payment or reduction or deferment of payment'

Trans Trust SPRL $v$ Danubian Co $L t d^{18}$ is another English case which raised the importance of autonomy principle when Denning LJ refers to necessity for seller to finance his own suppliers and as a result relies on provided LC by buyer for honouring his own account payables to the third party.

11 ARKINS, J.R.C.: Snow White V. Frost White: The New Cold War In Banking Law. In: Journal of International Banking Law, J.I.B.L., 2000, 15, 2, pp. 30-41.

12 Ward Petroleum Corp. v Federal Deposit Ins. Corp. (1990) 903 F.2d 1299.

13 DOLAN, J. F.: The Law of Letters of Credit: Commercial and Standby Credits. Rev. Ed. Boston: Warren, Gorham \& Lamont, 1996.

14 Eakin v Continental Illinois National Bank \& Trust Co. (1989) 875 F.2d 114, 116.

15 UCP600. Article 5.

16 Hamzeh Malas \& Sons v. British Imex Industries Ltd [1958] 2 QB 127; [1958] 2 WLR 100; [1958] 1 All ER 262, C.A.

17 United City Merchants (Investments) Ltd v Royal Bank Of Canada [1983] 1AC 168,183.

18 Trans Trust SPRL v Danubian Co Ltd [1952] 2QB 297 at 304. 
American case law also illustrates the importance of autonomy principle. For example in Semetex Corporation v UBAF Arab American Bank, ${ }^{19}$ US District court granted Semtex a summary Judgement against the UBAF on the basis of autonomy principle of Irrevocable Letters of Credit despite the fact that underlying contract was not performed due to the Executive Order which blocked all Iraqi assets in USA after Iraqi invasion to Kuwait on August 2, 1990.

Power Curber International Ltd v. National Bank of Kuwait $S A K^{20}$ is another case which prohibits applicant and issuing bank from dishonouring the credit based on nonperformance of the underlying contract.

\section{Uniform Commercial Code of USA}

In United States of America, Documentary Letters of Credit are governed by Article 5 of Uniform Commerical Code. Unlike earlier version of Article 5 of UCC, which did not point at the autonomy principle, ${ }^{21}$ revised version of UCC Article 5 clearly separates the undertaking of issuer in documentary letter of credit from existence, non-existence, performance or non-performance of underlying contract.

'the rights and obligations of an issuer to a beneficiary or a nominated person under a letter of credit are independent of the existence, performance, or non-performance of the contract or arrangement out of which the letter of credit arises or which underlie it, including contracts or arrangements between the issuer and the applicant and between the applicant and the beneficiary ${ }^{22}$

'an issuer is not responsible for the performance, non-performance of the underlying contract, arrangement, or transaction ${ }^{23}$

\subsubsection{Exceptions to the Autonomy Principle}

The autonomy principle provides beneficiary with the guarantee of the bank for payment against any issue within the terms of documentary Credits. ${ }^{24}$ Such guarantee desires payment to the beneficiary regardless to any dispute on the underlying contract, upon tender of complying documents. Therefore, the autonomy principle creates a weaker position for account party against abusive demands of beneficiary and his fraudulent claims. On such occasions, relying on strict compliance principle and rejection of non-complying documents by bank will be the only defence of applicant. However, this defence might not work when the beneficiary is determined to obtain payment on the basis of presenting fraudulent Documents. On the other hand, the beneficiary has the upper hand against the issuing bank and account party in which regardless to any dispute on the contract of sales, he is entitled for payment upon tender of complying documents. Such upper hand can be an incentive for abusive demand for payment or presentation of fraudulent documents by beneficiary. For a long period of time the general belief was supportive towards the absolute nature of independent principle. ${ }^{25}$ However, it became clear that exceptions are needed to deal with abusive and fraudulent demands. As result, the fraud exception has been established which is recognized by all common law and many

19 [1995] 2Bank LR 73.

20 [1981]2 Lloyd's Rep 394.

21 ENONCHONG, N.: The independence principle of letters of credit and demand guarantees. Oxford: Oxford University Press, 2011

22 UCC. Article 5- 103(d).

23 UCC. Article 5-108(f)(1).

24 ENONCHONG, N.: The independence principle of letters of credit and demand guarantees. Oxford: Oxford University Press, 2011, p. 93.

25 United City Cooperation v. Allied Arab Bank (1985) 2 Lloyds Rep. 554, 561. 
civil law countries. In cases of fraud, court has the obligation to decide between respecting the principle of autonomy and grating injunction to stop payment after considering public policy, statutes, public interest and third party rights. ${ }^{26}$ Despite the fact that Fraud rule is a recognized expectation to principle of autonomy of documentary credits, there is no standard ${ }^{27}$ regarding time and circumstances in which it should supersede the autonomy principle. ${ }^{28}$ Later it became clear that the public interest requires application of exceptions in case of illegal underlying contract. ${ }^{29}$ Therefore, clear evidences show that English Legal system is ready to recognize exceptions to the principle of autonomy.

\subsection{Fraud Exception}

In fact, Fraud is very old and well-known phenomenon in the business world. "As long as there have been commercial systems in place there have been those who have tried to manipulate these systems." ${ }^{30}$ Fraud has been considered as the "the most controversial and confused area" ${ }^{31}$ as it "goes to the very heart" of the letter of credit by providing the bank to look at the facts behind complying presentation of beneficiary and stop payment in cases of fraud in transaction. ${ }^{32}$

\section{LEGAL APPROACH TO LC FRAUD EXCEPTION}

\subsection{The American View}

In this section, American approach to LC fraud will be reviewed. In doing so, principle case of Sztejn v. J.Henry Schroder is going to be studied. Sztejn case is known for laying the foundation of LC fraud exception in the United States of American and also in England. Further, Article 5-109 of Unified Commercial Code as statuary body of law regulating Fraud in LC operation in the United States and grant of injunction as a judiciary remedy to fraud will be analysed.

\subsubsection{Sztejn v. J. Henry Schroder banking Corporation ${ }^{33}$}

This is the leading case on fraud rule in the United States of America that seriously affected development of fraud exception in documentary letters of credit. ${ }^{34}$ Another importance of Sztejn case is

26 GARCIA, R.L.F.: Autonomy principle of the letter of credit. In: Mexican Law Review, 2009, p. 69.

27 GAO, X.: The fraud rule in the law of letters of credit: a comparative study. Vol. 2. The Hague: Kluwer law international, 2002.

28 BUCKLEY, R.P. - GAO, X.: Comparative Analysis of the Standard of Fraud Required under the Fraud Rule in Letter of Credit Law. In: Duke J. Comp. \& Int'l L., 2003, 13, p. 293.

29 ENONCHONG, N.: The Autonomy Principle of Letters of Credit: An Illegality Exception? In: Lloyd's Maritime and Commercial Law Quarterly, 2006, p. 404.

30 Trade Finance Fraud -Understanding the Threats and reducing the Risk. A Special Report prepared by the ICC International Maritime Bureau. Paris: ICC International Maritime Bureau, 2002, p. 9.

31 BUCKLEY, R.P. - GAO, X.: The Development of the Fraud Rule in Letter of Credit Law: The Journey so Far and the Road Ahead. In: University of Pennsylvania Journal of Economic Law, 2002, 23, p. 663.

32 BUCKLEY, R.P. - GAO, X.: Comparative Analysis of the Standard of Fraud Required under the Fraud Rule in Letter of Credit Law. In: Duke J. Comp. \& Int'1 L., 2003, 13, p. 293.

33 (1941) 31 N.Y. S.2d 631.

34 BUCKLEY, R.P. - GAO, X.: The Development of the Fraud Rule in Letter of Credit Law: The Journey so Far and the Road Ahead. In: University of Pennsylvania Journal of Economic Law, 2002, 23, p. 676. 
being a reference in process of codification of 1962 version of UCC as well as being the principle authority for latter cases on fraud in LC operation. ${ }^{35}$ Gao refers to Sztejn case as "it shaped the fraud rule in virtually all jurisdictions".36

In this case, based on the international contract of sale between Sztejn (the buyer) and Transea Traders Ltd (the Seller), documentary letter of credit issued by Schroder (the issuing bank) as the method of payment with the draft drawn by issuing bank on the Chartered bank (presenting bank). Before presentation of documents to the bank, applicant (Sztejn) demanded court for granting injunction against beneficiary based on receiving "cow hair, other worthless material and rubbish with intent to simulate genuine merchandise and defraud the plaintiff" ${ }^{37}$ Sztejn also named Chartered bank as collecting bank not the holder in due course of the draft issued by issuing bank. Justice Sheintag of the New York Court of Appeal considered all allegations in case as truth and rejected to motion of Chartered Bank to dismiss the compliant of Sztejn on the basis of two arguments: allegation and established fact of fraud being committed within the framework of underlying contract. His statement started as following:

"It is well established that a letter of credit is independent of the primary contract of sale between the buyer and the seller. The issuing bank agrees to pay upon presentation of documents, not goods. This rule is necessary to preserve the efficiency of the letter of credit as an instrument for the financing of trade." 38

And continued on necessity to overrule the principle of independence in case of committing fraud by beneficiary:

"Of course, the application of this doctrine [the principle of independence] presupposes that the documents accompanying the draft are genuine and conform in terms to the requirements of the letter of credit.

However, I believe that a different situation is presented in the instant actions. This is not a controversy between the buyer and seller concerning a mere breach of warranty regarding the quality of the merchandise; on the present motion, it must be assumed that the seller has intentionally failed to ship any goods ordered by the buyer. In such a situation, where the seller's fraud had been called to the bank's attention before the drafts and documents have been presented for payment, the principle of the independence of the bank's obligation tinder the letter of credit should not be extended to protect the unscrupulous seller... Although our courts have used broad language to the effect that a letter of credit is independent of the primary contract between the buyer and seller, that language was used in cases concerning alleged breaches of warranty; no case has been brought to my attention on this point involving intentional fraud on the part of the seller which was brought to the bank's notice with the request that it withhold payment of the draft on this account." ${ }^{39}$

Court dismissed the motion of Chartered Bank against complaint of plaintiff and granted injunction to Sztejn:

35 In 1964 version of UUC fraud rule was under Article 5 section 5-114, but after revision of 1995 it is under Article 5 , section 5-109.

36 KELLY-LOUW, M.: Selective legal aspects of bank demand guarantees (Doctoral dissertation). Pretoria: University of South Africa, 2009, p. 179.

3731 NYS 2d 631 (1941) 633

38 Ibid., p. 632.

39 Ibid., p. 633 
"Transea was engaged in a scheme to defraud the plaintiff..., that the merchandise shipped by Transea is worthless rubbish and that Chartered Bank is not an innocent holder of the draft for value but is merely attempting to procure payment of the draft for Transea's account." ${ }^{\prime 0}$

The case of Sztejn is also important for recognizing the immunity of the holder in due course as well as bank security as a supporting reason in application of fraud exception:

"While the primary factor in the issuance of the letter of credit is the credit standing of the buyer, the security afforded by the merchandise is also taken into account. In fact, the letter of credit requires a bill of lading made out to the order of the bank and not the buyer. Although the bank is not interested in the exact detailed performance of the sales contract, it is vitally interested in assuring itself that there are some goods represented by the documents." ${ }^{1}$

"On this motion only the complaint is before me and I am bound by its allegation that the Chartered Bank is not a holder in due course but is a mere agent for collection for the account of the seller charged with fraud. Therefore, the Chartered Bank's motion to dismiss the complaint must be denied, if it had appeared from the face of the complaint that the bank presenting the draft for payment was a holder in due course, its claim against the bank issuing the letter of credit would not be defeated even though the primary transaction was tainted with fraud." ${ }^{42}$

\subsubsection{Article 5 of the Unified Commercial Code}

Article 5 of the Unified Commercial Code is governing the operation of Documentary Letters of Credits besides Case Law in the United States of America. The UCC had a permanent editorial board which published commentaries often cited by judges as an authority for explanation of different provisions. ${ }^{43}$ Article 5 of the current version of UCC is fully allocated to Documentary Letters of Credit. Drafting committee was following the goal of finding a way for further harmonization of US law with international regulations besides flexibility in practice to meet technological changes and keep the competitive position of LC in international trade. Article 5 of the UCC also contains relevant provisions in LC fraud exception. ${ }^{44}$

Current Article 5-109 titled "Fraud and Forgery" covers circumstances necessary for granting interlocutory injunction, the text of article describing such circumstances as following:

"(a) If a presentation is made that appears on its face strictly to comply with the terms and conditions of the letter of credit, but a required document is forged or materially fraudulent, or honour of the presentation would facilitate a material fraud by the beneficiary on the issuer or applicant: (1) the issuer shall honour the presentation, if honour is demanded by (i) a nominated person who has given value in good faith and without notice of forgery or material fraud, (ii) a confirmer who has honoured its confirmation in good faith, (iii) a holder in due course of a draft drawn under the letter of credit which was taken after acceptance by the issuer or nominated person, or (iv) an assignee of the issuer's or nominated person's deferred obligation that was taken for value and without notice of forgery or material fraud after the obligation was incurred by the

40 Ibid.

41 Ibid., p. 634-635

42 Ibid.

43 ZHANG, Y.: Approaches to Resolving the International Documentary Letters of Credit Fraud Issue. Doctoral Dissertation. Joensuu: University of Eastern Finland, 2011, p. 74.

44 UCC, Article 5 -109. 
issuer or nominated person; and (2) the issuer, acting in good faith, may honour or dishonour the presentation in any other case.

(b) If an applicant claims that a required document is forged or materially fraudulent or that honour of the presentation would facilitate a material fraud by the beneficiary on the issuer or applicant, a court of competent jurisdiction may temporarily or permanently enjoin the issuer from honouring a presentation or grant similar relief against the issuer or other persons only if the court finds that: (1) the relief is not prohibited under the law applicable to an accepted draft or deferred obligation incurred by the issuer; (2) a beneficiary, issuer, or nominated person who may be adversely affected is adequately protected against loss that it may suffer because the relief is granted; (3) all of the conditions to entitle a person to the relief under the law of this State have been met; and (4) on the basis of the information submitted to the court, the applicant is more likely than not to succeed under its claim of forgery or material fraud and the person demanding honour does not qualify for protection under subsection (a) (1)."

Text of UCC article 5-109 follows two main directions of "fraud immunisation" and "fraud exception". ${ }^{45}$ An important aspect of Article 5-109 (a) is clarification of the fact that fraud is applicable both to forgery in documents stipulated in the Credit and in underlying sales contract. Article also comments on necessity of fraud to be material in order to issue injunctive relief. However, it does not define what does it mean for fraud to be material? Whereby, official comment on the Article provides: "the beneficiary has no colourable (meaningful) right to expect honour and where there is no basis in fact to support such a right to honour" ${ }^{46}$

Neither text of article 5-109 nor its official commentary refer to intention of beneficiary to defraud. As a result, it has been argued that UCC article 5-109 has focus on seriousness of fraud in the course of transaction, not beneficiary's intention and state of mind. ${ }^{47}$ It is clear from the official commentary that standard of proof for fraud is set high and mere allegation of fraud is not sufficient for granting injunction to applicant. ${ }^{48}$ Injunction will be granted only after meeting high standard of proof for the purpose of preventing threats to independence principle in LC operation. Commentary also stipulates that granting similar reliefs like attachment and declaratory judgement by court should follow similar high standards. ${ }^{49}$ Attachment is a sort of preliminary relief to secure or seize the disputed property following the objective to force compliance with court decision on pending case. ${ }^{50}$ Declaratory Judgement refers to court judgement in determining the rights of parties under, a statute, a contract or a will, on the basis of any fact or law.

Scholars consider the US approach to fraud in documentary letters of credit as "unduly narrow approach" ${ }^{51}$ which limits the application of LC fraud exception. ${ }^{52}$ Different interpretations of judges

45 WUNNIKE, B. - WUNNICKE, Diane B.: Standby and Commercial Letters of Credit. 2nd ed, New York: Wiley Law Publications, 1996, pp. 165-179.

46 UCC Article 5 Letters of Credit, UCC\$5-109 Forgery and Fraud, Official Comment 1.

47 BUCKLEY, R. P.: The 1993 Revision of the Uniform Customs and Practice for Documentary Credits. In: Journal of Banking \& Finance Law \& Practice, 1995, 77, p. 97.

48 UCC Article 5 Letters of Credit, UCC \$5-109 Forgery and Fraud, Official Comment 4.

49 Ibid.

50 FLETCHER, G. P. - SHEPPARD, S.: American Law in a Global Context: The Basics. Oxford; New York: Oxford University Press, 2005, p. 511.

51 BARENS, J. G. - BYRNE, J. E.: Letters of Credit: 2000. In: Business Law, 2001, 56, 4. Reprinted in: Annual Survey of Letter of Credit Law \& Practice, 2002, 13, 18.

52 BARENS, J. G. - BYRNE, J. E.: Letters of Credit. In: BYRNES, J. E. - BYRNES, Ch. S. (Eds.): Annual Survey of Letter of Credit Law and Practice. Montgomery Village, MD: The Institute of International Banking Law \& Practice, Inc., 2007, pp. 39-42. 
from standard of proof are also a discouraging factor. ${ }^{53}$ This can be a disadvantage for American law to show different interpretations of judges from a single problem in presence of uniform standard of "material fraud". ${ }^{54}$

\subsection{English Law}

Under English Law, Documentary Letters of Credit are considered as the life blood of the commerce ${ }^{55}$ while fraud is considered as "the most controversial and confused area" ${ }^{\text {"56 }}$ as it affects the independence principle in international operation of LC. Historically, English courts take a restrictive approach to interfering in obligation of bank to pay unless there is a corroborate evidence of committing fraud by beneficiary. Even nullity and illegality of underlying sales contract do not affect the court decision to interrupt the regular operation of LC by issuing stop order payment to bank. ${ }^{57}$ Unlike American law, there is no statute regulating LC fraud rules in England and this area of law has been consistently governed by case law from late 1970s until today.

English law does not have any definition for fraud and court should conclude its establishment on the case by case basis. However, according to existing authorities, there are four main types of LC fraud disputes distinguished in English Law. First, beneficiary sues the bank on the basis of bank's rejection to pay despite receiving compliant presentation. Second, Bank has payed beneficiary, however, sues beneficiary due to presentation of fraudulent documents and request for restitution of the payment. Third, paying bank sues the issuing bank in request for reimbursement after effectuating the payment, and refusal of issuing bank to reimburse on the basis of fraud. Finally, before effectuating the payment by bank, applicant requests interlocutory injunction from court to stop bank from payment on the basis of beneficiary's fraud. ${ }^{58}$

In similar way to American Law, it seems that under English law injunction is the most popular legal relief sought by applicant against either bank or beneficiary in cases of LC fraud. However, restrictive approach of English courts to interfere in independence principle of Documentary Letters of Credit creates doubt in usefulness of such remedy. This section explores non harmonious approach of English courts to different types of LC fraud disputes with special focus on procedural aspects of interlocutory injunction in England.

\subsubsection{Bank's rejection to pay}

Upon presentation of confirming documents by beneficiary, issuing bank and conforming bank have the duty to honour the presentation. ${ }^{59}$ In case of bank's decision not to effect the payment to

53 BUCKLEY, R.P. - GAO, X.: Comparative Analysis of the Standard of Fraud Required under the Fraud Rule in Letter of Credit Law. In: Duke J. Comp. \& Int'l L., 2003, 13, p. 322.

54 MOONEY, J. L. - BLODGETT, M. S.: Letters of Credit in the Global Economy: Implications for International Trade. In: Journal of International Accounting, Auditing and Taxation, 1995, 4, 2, p. 183.

55 Horbottel v. National Westminster Bank [1978] QB 146;100.

56 BUCKLEY, R.P. - GAO, X.: The Development of the Fraud Rule in Letter of Credit Law: The Journey so Far and the Road Ahead. In: University of Pennsylvania Journal of Economic Law, 2002, 23, p. 663.

57 D'ARCY, L.: Schmitthoff's Export Trade - The law and Practice of International Trade. 10th ed, London: Sweet \& Maxwell, 2000, p. 166.

58 MALEK, A. - QUEST, D.: Documentary Credits - The Law and Practice of Documentary Credits Including Standby Credits and Demand Guarantees. 4th Ed. Haywards Heath, West Sussex: Tottel, 2009, para 9.2, pp. 207-208.

59 Ibid, p. 264. 
beneficiary, it should prove the establishment of fraud based on existing standard of proof introduced by English Courts ${ }^{60}$ (discussed in injunction chapter of current paper). However, it is rare that the bank refuses to honour the credit on its own initiative. ${ }^{61}$ Banks generally do not reveal fraud and the information and instructions about fraud come from account party. After receiving allegation of fraud from account party, bank has the option to pay or not. In case it decides to effect the payment, obtaining the injunction from court will be the only solution for account party to prevent payment to beneficiary. ${ }^{62}$ If bank decides not to pay, then either beneficiary's fraud is established and bank will be excused from payment or if happened otherwise, bank will be in breach of contract. When bank decides not to effectuate the payment, beneficiary might apply for summary judgement against the bank in order to get quick remedy without going to full trial. ${ }^{63}$ Issuing the summary judgement by court in England is subject to the English Civil Procedural Rules (CPR). Part 24.2. reads accordingly:

"The court may give summary judgment against a claimant or defendant on the whole of a claim or on a particular issue if -

(a) it considers that: (i) that claimant has no real prospect of succeeding on the claim or issue; or (ii) that defendant has no real prospect of successfully defending the claim or issue; and

(b) there is no other compelling reason why the case or issue should be disposed of at a trial." ${ }^{\prime 64}$

The decision of courts in Solo Industries v Canara Bank, ${ }^{65}$ Safa Ltd $v$ Banque du Caire ${ }^{66}$ and Banque Saudi Fransi $v$ Lear Siegler Services $\operatorname{Inc}^{67}$ show that in case of beneficiary's application for summary judgement, bank is subject to a higher standard than what is required in CPR 24.2 . Therefore, for court, it is not sufficient that bank can show a real prospect of successfully establishing fraud in its defence. In addition, bank is required to prove the real established fraud "which has the capability of being clearly established at the interlocutory stage". ${ }^{68}$. In occasions that bank does not resist payment on the basis of fraud rule like refraining to pay based on invalidity of letter of credit, it would be sufficient to satisfy the normal standard ${ }^{69}$ while trying to show the real prospect of success under CPR 24.2.

\subsubsection{Bank's Entitlement for Reimbursement}

General rule is that the bank which has paid against conforming presentation is entitled for reimbursement. However, in case of fraud, bank has no obligation against beneficiary or entitlement against the account party to effect the payment. In case of payment in such circumstances, bank cannot claim for reimbursement. ${ }^{70}$ However, the bank which does not have information about the fraud of beneficiary will not be prejudiced.

60 Ibid.

61 ELlingER, P. - NOE, D.: The Law and Practice of Documentary Letters of Credit. Oxford : Hart Publishing, 2010, p. 145.

62 Ibid.

63 Ibid.

64 Part 24.2 of the Civil Procedure Rules. Available at: athttp://www.hrothgar.co.uk/YAWS/rules/part24.htm\#IDAZBHOB

65 Solo Industries UK Ltd v Canara Bank [2001] 1 WLR 1800.

66 Safa Ltd v Banque du Caire [2000] 2 Lloyd's Rep.600.

67 Banque Saudi Fransi v Lear Siegler Services Inc. [2007] 2 Lloyd‘s Rep 47.

68 Ibid., p. 31-32.

69 Ibid., p. 33.

70 ELLINGER, P. - NOE, D.: The Law and Practice of Documentary Letters of Credit. Oxford : Hart Publishing, 2010, 
In the case of Angelica-Whitewear Ltd $v$ Bank of Nova Scotia ${ }^{71}$ which was referenced by English courts, Le Dien J. from the Supreme court of Canada argued that it case of improperly paid draft by issuing bank the standard of proof for fraud should be set in the question "Whether fraud was so established to the knowledge of issuing bank before payment of the draft as to make the fraud clear or obvious to the bank". ${ }^{72}$ According to Le Dien J, standard of proof for such cases was different from standard of proof when applicant is trying to obtain interlocutory injunction against bank to restrain the payment to the beneficiary. He explained that in latter case the "strong prima facie test will apply".73

As discussed before, it can be understood that the bank which is trying to resist summary judgement against the payment to beneficiary is subject to the higher standard of proof. However, this does not apply in the occasion that applicant, issuing bank or confirming bank try to resist the summary judgment as a result of being sued for reimbursement by the bank which has paid the fraudulent beneficiary. ${ }^{74}$ In such occasions, defendant is expected to provide a real prospect of existing fraud and satisfy the normal test of CRP Part 24.2 at trial. ${ }^{75}$

In case of Banque Saudi Fransi $v$ Lear Siegler Inc, ${ }^{76}$ the issuer of a performance bond was seeking for summary judgement against the instructing party who provided a counter indemnity. After making the payment to the beneficiary defendant, issuing bank raised the defence of not being bound for payment under the country indemnity due to dishonest claim of the beneficiary. In trial, defendant managed successfully resist against the summary judgement by showing the real prospect which was clearly established. ${ }^{77}$ In the above decision, it is implied that although beneficiary might successfully obtain the summary judgement against bank as a result of bank's failure to establish a clear evidence of fraud, there is no guarantee that bank can in return obtain summary judgement for receiving reimbursement against the instructing party. Because the instructing party should only meet requirements of the low test of real prospect of fraud in the trial. ${ }^{78}$

\subsubsection{Fraud in deferred payment obligations}

Under the deferred payment credits, the nominated bank has the obligation to pay on the maturity date in accordance with the credit terms. As under deferred payment system there is no immediate payment available to seller until the date of maturity of credit, the seller is responsible to ship goods and expects payment on maturity. Such process will impose financial burden on seller. Therefore, market demand in similar conditions resulted in creation of forfaiting practice. In forfaiting practice, nominated bank may agree to discount the beneficiary's documents and expect reimbursement from issuing bank on maturity date. In case of beneficiary's fraud before the maturity date, applicant and issuing bank will definitely try not to reimburse the nominated bank which has paid to fraudulent beneficiary. Despite the fact that establishment of beneficiary's fraud will depend on facts of each

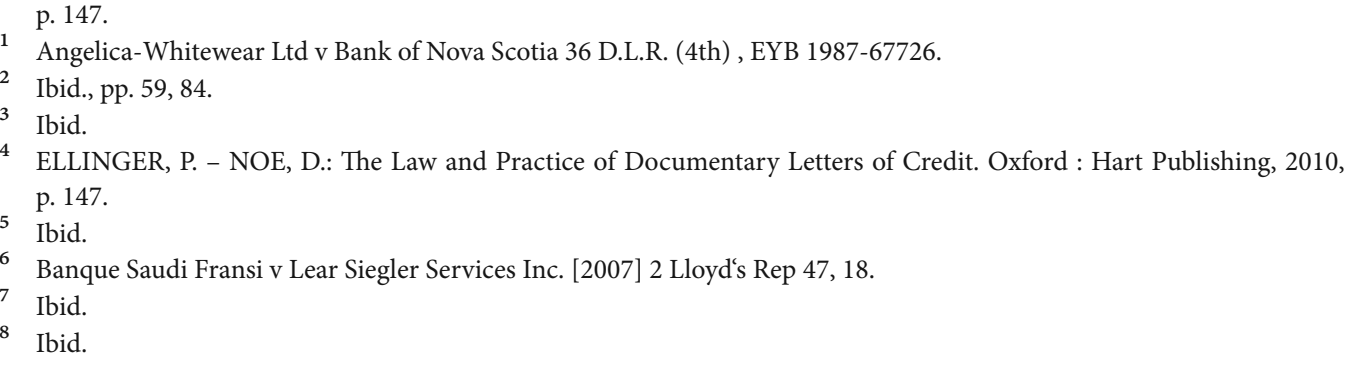


individual case and in addition guideline for interbank reimbursements under differed payment is provided by UCP 600, it is worth to review the right and obligations of involved financial institutions under deferred payment before and after coming into force of the UCP 600.

\subsubsection{The standard of proof}

When account party is looking for injunction to prevent beneficiary from demanding payment or bank from enforcing payment on the basis of fraud exception, the first necessary step to take is meeting the standard of proof. ${ }^{79}$ In the case of United City Merchants (Investment) Ltd $v$ Royal Bank of Canada, ${ }^{80}$ the standard of proof for fraud was considered when Lord Diplock held the requirement as "Clear, obvious, or established fraud known to the issuer or confirmer of the letter of credit." ${ }^{11}$ Also Ackner LJ , in the case of United Trading Corp. SA v Allied Arab Bank Ltd ${ }^{82}$ laid down the standard of "only realistic inference" in order to provide an alternative to the "clear evidence" provided by Lord Diplock in United City Merchants. Ackner LJ further emphasized that:

(a) "The evidence of fraud must be clear, both as to the fact of the fraud and as to the [guarantor's] knowledge. The mere assertion or allegation of fraud would not be sufficient... We would expect the court to require a strong corroborative evidence of the allegation, usually in the form of contemporary documents, particularly those emanating from the buyer." ${ }^{\prime 3}$

Court also commented:

(b) "for the evidence of fraud to be clear, it would be expected that the buyer was given the necessary opportunity to answer the allegation against him and he (buyer) fails to provide any, or any adequate answer in circumstances where one could properly be expected."

Other similar positon was taken by Mance LJ in The Court of Appeal of Solo Industries UK Ltd v. Canara Bank. ${ }^{85}$ Mance LJ while responding to the contention of bank towards standard of proof which should preclude "any possibility of innocent explanation" took a very close position to the position of United Trading Corp SA. From what has been discussed so far, it can be clearly understood that standard of proof for fraud under English law has been formulated differently. One reason can be that courts try to set not too high standard from one hand to safeguard the autonomy principle and on the other hand set it too high not to be attainable in practice. As a result, there are different standards of proof including "established or obvious fraud", "good arguable case which is the realistic inference on the material available for beneficiary to be fraudulent" 87 or the "real prospect" 88 of establishing fraud.

\footnotetext{
79 Discount Record Ltd v Barclays Bank Ltd [1975] 1WLR 315; RD Harbottle (Mercantile) v National Westminster Bank [1978] QB 146; Edward Owen Engineering Ltd v Barclays Bank International Ltd [1978] QB 159; Bolivinter Oil SA v Chase Manhattan Bank [1984] Lloyd’s Rep 251; Group Josi Re v Walbrook Insurance Co Ltd [1996] 1 WLR 1152.

80 United Trading Corp. SA v Allied Arab Bank Ltd, [1985] 2 Lloyds Rep 554, 561.

81 Ibid.

82 Ibid.

83 Ibid.

84 Ibid.

85 Solo Industries v Canara Bank [2001] 2 Lloyd's Rep 578.

86 Edward Owen Engineering Ltd v. Barclays Bank International [1978]QB 159, per Lord Denning.

87 United Trading Corporation SA v. Allied Arab Bank at FN 27 per Ackner LJ at 561.

88 Solo Industries UK Ltd v Canara Bank [2001] 1 WLR 1800, [2001]EWCA Civ 1059.
} 
The second step for obtaining the injunction is satisfying the balance of convenience.

The issue was not always considered in English court's decision while deciding to grant injunction base on fraud. One reason is that in most cases evidence was not enough to establish fraud and as a result the case did not proceed to the stage for considering the balance of convenience. ${ }^{89}$ Therefore, when claimant manages to establish the basis for injunction, court will consider the balance of convenience in order to issue the injunction. ${ }^{90}$ It has been mentioned that in the context of injunctions to prevent either beneficiary from claiming the payment or bank form effecting the payment in most cases balance of convenience is against granting the injunction.

The main reasons against granting injunction can be named as resistance of adequate remedies for damages, imminent expiry date of credit, availability of freezing injunction and availability of final accounting between parties. ${ }^{91}$

\subsection{UCP's view}

The Unified Customs and Practices for Documentary Letters of Credit (currently UCP600) were published by ICC for the first time in 1933. UCP is considered as one the most successful private initiatives in regulating international trade practice. Article 5 of the UCP has recognized the principle of autonomy in LC transaction by emphasizing that bank deals with documents not goods and liability of bank is limited to pay to beneficiary against presentation of complying documents. ${ }^{92}$ However, it takes an absolutely silent position towards fraud and leaves it open for national laws. ${ }^{93}$ To justify their approach, ICC authorities point at different ways to address the problem of abusive demand and fraud in different jurisdictions and consider protection of parties in good faith as responsibility of national courts. ${ }^{94}$ Many scholars confirm the sensitivity of fraud and different approaches of national jurisdictions to it by considering the silent approach of UCP to fraud exception as a ground-breaking success. ${ }^{95}$ They argue that current approach of UCP to fraud encourages national courts to deal with this problem without any negative effect on the market position of Documentary Letters of Credit as popular trade finance tool in international trade. ${ }^{96}$ In the same vein, Goode comments: "the content and explanation of ICC Uniform Rules are influenced by the fact that these uniform rules are rules of best banking practice, not the rules of law..." while fraud is "the province of the applicable law of the courts of the forum". ${ }^{97}$

89 ENONCHONG, N.: The independence principle of letters of credit and demand guarantees. Oxford: Oxford University Press, 2011, p. 158.

90 Ibid., p. 236.

91 Ibid.

92 UCP 600 , Article 5.

93 Opinions of the ICC Banking Commission - On Queries relating to Uniform Customs and Practice for Documentary Credits 1984-1986. Edited by Bernard Wheble. Paris: ICC Publishing S.A., 1987, p. 23; KURKETLA, M.: Letters of Credit Under International Trade Law: UCC, UCP and Law Merchant. New York, London \& Rome: Oceana Publications. Inc., 1985, pp. 31-32; COYLLER, G.: Presentation in Seminar 'UCP 600: Understanding the New Documentary Credits Rules', organized by ICC Finland, Helsinki, 21 March, 2007.

94 Opinions of the ICC Banking Commission 1995-1996, ICC Publication No. 565. Paris: ICC, 1997, p. 22; Query: Rights of Recourse to the Beneficiary in the event of Fraud. In: Latest Queries Answered by the ICC Banking Commission'. In: DCI (ICC), Spring 1997, 3, 2, p. 7.

95 DOLAN, J. F.: Commentary on Legislative Developments in Letter of Credit Law: An Interim Report. In: Banking \& Fin. L. Rev., 8, 2002, 53, p. 63.

96 Ibid.

97 GOODE, R.: Abstract Payment Undertakings and the Rules of the International Chamber of Commerce. In: Saint Louis University Law Journal, 1995, 39, pp. 725-727. 
This would convey the meaning that despite recognition of the problem of fraud by drafters of UCP, ${ }^{98}$ they have intentionally set it aside. ${ }^{99}$

Leacock considers UCP approach to LC fraud as "unqualified liability". ${ }^{100}$ He further explains that with reference to independent principle, paying bank does not have any liability for beneficiary's fraud in case of paying against confirming documents even after receiving notice from applicant. ${ }^{101}$

However, UCP's silent approach to fraud has been criticized by other scholars on the basis that regulations should provide secure and predictable environment for trading partners, where different approaches of national laws to fraud is unsatisfactory as there is no certainty provided for businessmen who intend to enter international trade. ${ }^{102}$ Inclusion of fraud rule in UCP is one of the recommended solutions for non-harmonized approaches of national laws to this problem. ${ }^{103}$ Drafting a set of transnational trade law with special focus on non-harmonized aspects of international LC operation including fraud is another scholarly proposal ${ }^{104}$ which does not seem realistic due to time consuming process of ratification of such draft by different nations. ${ }^{105}$ In brief, fraud exception is excluded from UCP and left under the discretion of national law. This approach of ICC has been denounced by some scholars who consider it as a reason for uncertainty in international trade while others call it a successful step towards increasing international marketability of Documentary Letters of Credit. ${ }^{106}$

\subsection{1 e-UCP}

"This is the acronym for the supplement to the uniform Customs and Practice for Documentary Credits for Electronic Presentation" ${ }^{107}$ Meeting the needs for electronic trade was the initiative of Banking Commotion of ICC to propose the formation of committee to work on developing a bridge between UCP and processing the electronic equivalent of paper based credits. The working group started to work on preparation of a supplement to the UCP which "would deal with the issues of Electronic Presentation". ${ }^{108}$ The result of working group's efforts is known as eUCP. It came into force from 1 April 2002 and the format facilitates further revisions. ${ }^{109}$ Current version of eUCP is the

98 DOLAN, J. F.: The Law of Letters of Credit: Commercial and Standby Credits. Rev. Ed. Boston: Warren, Gorham \& Lamont, Incorporated, 1996, p. 63.

99 BARSKI, K. A.: Letters of Credit: A Comparison of Article 5 of the Uniform Commercial Code and the Uniform Customs and Practice for Documentary Credits. In: Loy. L. Rev., 1996, 41, pp. 735-751.

100 LEAKOCK, S. J.: Fraud in International Transaction: Enjoining Payment of Letters of credit in International Transactions. In: Vand. J. Transnat'l L., 885,1984 (Fall), 17, p. 912.

101 Ibid., p. 913.

102 BUCKLEY, R.P. - GAO, X.: The Development of the Fraud Rule in Letter of Credit Law: The Journey so Far and the Road Ahead. In: University of Pennsylvania Journal of Economic Law, 2002, 23, p. 701.

103 KUO-ELLEN, L. S.: UCP Needs to Change. In: Journal of Money Laundering Control, 2002, 5, 3, p. 231.

104 ROWE, M.: Do We Need a Transnational Law on Documentary Credits? Michael Rowe \& Bernard Wheble Debate. In: DCI (ICC), 1998, Spring, 4, 2, pp. 16-17.

105 Ibid.

106 BUCKLEY, R.P. - GAO, X.: The Development of the Fraud Rule in Letter of Credit Law: The Journey so Far and the Road Ahead. In: University of Pennsylvania Journal of Economic Law, 2002, 23, 676.

107 BUCKLEY, R.P. - GAO, X.: Comparative Analysis of the Standard of Fraud Required under the Fraud Rule in Letter of Credit Law. In: Duke J. Comp. \& Int'l L., 2003, 13, p. 113.

108 Ibid.

109 Ibid., p. 114. 
version 1.1. Issues covered by eUCP are: "eUCP- UCP relations, format, presentation, originals and copies and examination of electronic records". ${ }^{110}$ Article 2 of eUCP emphasized the consistency of all articles of eUCP with UCP while their application is limited only to cases of electronic presentation. While using the eUCP, credit will be also subject to UCP without any express incorporation of it. ${ }^{111}$ Alongside with UCP, the same silent position towards fraud has been taken in e-UCP.

\subsection{Uniform Rules of Contract Guarantees (URCG)}

URCG was introduced by ICC in early 1970s in order to address the need for set of rules which deal with existing inconsistencies in field of "[g]uarantees given by banks, insurance or services or the performance of work." ${ }^{12}$ Therefore, unlike UCP which was regulating the process of Letter of Credit, URCG was an attempt to deal with unfair calls for demand guarantees which can be considered as a measure to address problem of fraud. ${ }^{113}$ Despite all expectations, URCG was not welcomed by the international business society for few reasons including: the problem that applicability of URCG was only limited to independent guarantees and it had no effect on accessory guarantees. ${ }^{114}$

The other problem was the result of URCG's attempt to prevent unfair call on demand guarantees by requiring beneficiary to produce an evidence of failure in the format of judgement, arbitral award or the principal's written approval at the time of making the claim. ${ }^{115}$

It is submitted that fraud in documentary letters of credit has not been fully addressed under article 9 of URCG. ${ }^{116}$ Gao believes that while article 9 of URCG enumerates condition for payment under independent guarantees will be due, fraud rule covers situation that permits instruction of payment under bank guarantee or letter of credit. ${ }^{117}$ As a result, it is possible to conclude that drafters of URCG tried to tap on the problem of fraud but the final outcome lacks any sort of precision.

\footnotetext{
110 Ibid.

111 Ibid.

112 Int'l Chamber of Commerce. ICC Publication No. 325. Paris: ICC, 1978, p. 7.

113 URCG, Article 9:

If a guarantee does not specify the documentation to be produced in support of a claim or merely specifies only a statement of claim by the beneficiary, the beneficiary must submit:

(a.) in the case of a tender guarantee, his declaration that the principal's tender has been accepted and that the principal has then either failed to sign the contract or has failed to submit a performance guarantee as provided for in the tender, and his declaration of agreement, addressed to the principal, to have any dispute on any claim by the principal for payment to him by the beneficiary of all or part of the amount paid under the guarantee settled by a judicial or arbitral tribunal as specified in the tender documents or, if not so specified or otherwise agreed upon, by arbitration in accordance with the Rules of the ICC Court of Arbitration or with the UNCITRAL Arbitration Rules, at the option of the principal;

(b.) in the case of a performance guarantee or of a repayment guarantee, either a court decision or an arbitral award justifying the claim, or approval.

114 BUCKLEY, R.P. - GAO, X.: Comparative Analysis of the Standard of Fraud Required under the Fraud Rule in Letter of Credit Law. In: Duke J. Comp. \& Int'l L., 2003, 13, p. 114.

115 URCG, Article 8(3) and 9.

116 GAO, X.: The Fraud Rule under the UN Convention on Independent Guarantees and Standby Letters of Credit: A Significant Contribution from an International Perspective. In: George Mason Journal of International Commercial Law, 2010, Fall, p. 64

117 Ibid.
} 


\subsection{Uniform Rules for the Demand Guarantees (URDG)}

The failure of URCG in attracting the attention of the business society at global level was the reason for ICC to introduce new set of rules and take a different approach to Demand Guarantees. URDG 458 came into force by 1992 and was based on a model which was applied by British Bankers. ${ }^{118}$ Despite the fact that URDG 458 was strongly influenced by UCP, still "[w] orldwide acceptance of the Rules ha[s] been disappointing" ${ }^{119}$ URDG 758 which is the revised version of URDG 458 came into force on 1 July 2010. It tries to address problems of previous version and set out functions and obligations of parties to the demand-guarantee by reflecting the best practices in business of guarantees. ${ }^{120}$

Similar to URCG, it is not possible to find a direct approach to fraud in URDG. However, article 20 of the URDG takes an implicit approach to fraud. ${ }^{121}$ Clear similarity between article 20 of URDG and article 9 of URCG shows intention of drafters towards providing a safety mechanism for payment under guarantee rather than direct reference to a measure which can prevent fraud.

\subsection{International Standard Practice (ISP 98)}

"ISP.98 is a set of rules specifically designed for standby letters of credit". ${ }^{122}$ It was originally introduced by American institute of International Banking Law and Practice. ISP 98 received approval by ICC in $1998^{123}$ and came into effect by January 1999. Historically, Standby Letters of Credits have been in use for many decades without being subject to specific regulations. They were mostly regulated by UCP, however, application of UCP to Standby Letters of Credits was source of many problems as UCP was «originally written for use only in commercial letters of credit... many of the provisions of the U.C.P. are either inapplicable or inappropriate in a standby credit context.» ${ }^{124} \mathrm{On}$ the other hand, it was possible for Standby Letters of Credit to be governed by URDG due to similarity between legal character of Demand Guarantees and Standby Letters of Credits. However, URDG

118 Int'l Chamber of Commerce. ICC Publication No. 458. Paris: ICC, 1992.

119 KATZ, R.: Report delivered at the I.C.C. Hong Kong meeting. Reprinted in: Int'l Chamber of Commerce, ICC Publication No. 470/893. Paris: ICC, 1999, p. 19.

120 BARANAELLO, J.: Understanding the URDG 758. Available at: http://www.fpsc.com/DB/TreasuryPulse/ Fall2010/Article4.html

121 URDG Article 20 :

a) Any demand for payment under the Guarantee shall be in writing and shall (in addition to such other documents as may be specified in the Guarantee) be supported by a written statement (whether in the demand itself or in a separate document or documents accompanying the demand and referred to in it) stating:

(i) that the Principal is in breach of his obligation(s) under the underlying contract(s) or, in the case of tender guarantee, the tender conditions; and (ii) the respect in which the Principal is in breach.

b) Any demand under the Counter-Guarantee shall be supported by a written statement that the Guarantor has received a demand for payment under the Guarantee in accordance with its terms and with this Article.

c) Paragraph (a) of this Article applies except to the extent that it is expressly excluded by the terms of the Guarantee. Paragraph (b) of this Article applies except to the extent that it is expressly excluded by the terms of the Counter Guarantee.

122 BUCKLEY, R.P. - GAO, X.: Comparative Analysis of the Standard of Fraud Required under the Fraud Rule in Letter of Credit Law. In: Duke J. Comp. \& Int'l L., 2003, 13, p. 115.

123 Int'l Chamber of Commerce, ICC Publication No. 590. Paris: ICC, 1998.

124 TURNER, P.S.: New Rules for Standby Letters of Credit: The International Standby Practices. In: Banking \& Finance Law Review, 1999, 14, p. 459. 
is becoming more popular after coming into force of its new revision URDG 758 and «[f]rom the viewpoint of the I.C.C ..... Standby letters of credit continue to be covered by the U.C.P. and are not covered by the U.R.D.G.» ${ }^{125}$ Initially, similar to UCP for regulating the function of Commercial Letters of Credits URDG for Independent Guarantees, and ISP 98 was drafted for the purpose of regulating Standby Letters of Credits. However, «Like the UCP and the URDG, ISP98 [applies] to any independent undertaking issued subject to it». ${ }^{126}$

While article 20 of URDG tries to define a safety mechanism and reason for effectuating payment under the demand guarantee, Rules 4.16 ad 4.17 of ISP 98 provide that effectuating payment under the stand by letter of credit does not need any default or conditions relevant to underlying contract where such situation is not required by the credit. Therefore, it is possible to conclude that ISP 98 does not even address problem of fraud in an implied manner.

\subsection{United Nation's Convention on Independent Guarantees and Standby Letters of Credits}

UNCITRAL Convention has been drafted by an intergovernmental organization which is body of United Nations General Assembly and works on preparation of instruments for harmonization of law regarding international trade. ${ }^{127}$ Convention has been adopted by UN General Assembly on 11 December of $1995 .{ }^{128}$ Standby letters of credits and independent guarantees or any other international undertaking can be subject to the UCITRAL Convention, if: ${ }^{129}$

«the place of business of the guarantor/issuer at which the undertaking is issued is in a Contracting State,» or «the rules of private law lead to the application of the law of a Contracting State,» «unless the undertaking excludes the application of the Convention.»

In case of Commercial Letters of Credit, by express address of parties to the credit UNCITRAL Convention can be used as the governing law. ${ }^{130}$ Although, UCP and URDG have been used as bases for drafting the UNCITRAL Convention, it is possible to distinguish some differences among them. First, UCP and URDG have been drafted by ICC which is a private institute and its approvals might only have application as voluntary rules or self-regulations while UNCITRAL Convention is a uniform law and official regulation applied to signatory countries which has been drafted by an international organization. ${ }^{131}$ Therefore, UNCITRAL Convention can be differentiated from ICC rules due to its legal statues. In addition, UNCITRAL Convention, consists of complementary provisions to UCP 600, URDG and ISP 98 including abusive demand, fraud and remedies which are discussed under the section 19 of Convention.

\footnotetext{
125 Int'l Chamber of Commerce, ICC Publication No. 205-207. Paris: ICC, 1998.

126 BYRNE, J. E.: Preface. In: BYRNE, J. E. et al.: International Standbypractices ISP98 6. Paris: ICC Publishing, 1998.

127 Explanatory Note: UNCITRAL Secretariat on the United Nations Convention on Independent Guarantees and Stand-by Letters of Credit, U.N. Commission on International Trade Law, 30th Sess., note I, at 2, U.N. Doc. A/CN.9/431, 1996.

128 BUCKLEY, R.P. - GAO, X.: Comparative Analysis of the Standard of Fraud Required under the Fraud Rule in Letter of Credit Law. In: Duke J. Comp. \& Int'l L., 2003, 13, p. 117.

129 UNCITRAL CONVENTION Art. 1(2).

130 UNCITRAL CONVENTION Art. 1(1)(b).

131 UNCITRAL CONVENTION Art. 1(2).
} 


\subsubsection{UNCITRAL Convention's View}

In late 1995 the United Nations Convention on Independent Guarantees and Standby Letters of Credit came into force with the goal of facilitating the function of Independent Guarantees and Standby Letters of Credit in international trade. The Convention is effective in contracting States and despite the fact that its scope is limited to demand guarantees and standby letters of credit, it has application to Commercial Documentary Letters of Credit as well. This convention is the first international effort to address the problem of fraud in international LC transaction and three of its articles (article 15,19 and 20) directly deal with abusive and fraudulent demand for payment under standby letters of credit and independent guarantees plus ways to prevent them. Therefore, Convention is considered a supportive regulatory framework to UCP. However; the word fraud has not been mentioned throughout the convention following the logic of preventing confusions which may result from different interpretations of the term in different jurisdictions.

Article 15 is the guideline for beneficiary in making the demand under standby letters of credit and independent guarantees. It refers to conditions under which beneficiary's demand can be prevented: " $t]$ he beneficiary, when demanding payment, is deemed to certify that the demand is not in bad faith (for example by providing confirmation letters from an authorized inspection firm regarding compliance of shipped consignment with terms of LC)and that none of the elements referred to in subparagraphs (a), (b) and (c) of paragraph 1 of article 19 are present."

Article 19 titled: "Exceptions to payment obligation" provides list of situations which tackle issues with the possibility of refusing demanded payment by beneficiary. Paragraph (1) provides that: "Any document is not genuine or has been falsified; no payment is due on the basis asserted in the demand and the supporting documents; or Judging by the type and purpose of the undertaking, the demand has no conceivable basis..." . Paragraph 2 explains the meaning of "no conceivable basis": "(a)The contingency or risk against which the undertaking was designed to secure the beneficiary has undoubtedly not materialised; (b)The underlying obligation of the principal/applicant has been declared invalid by a court or arbitral tribunal, unless the undertaking indicates that such contingency falls within the risk to be covered by the undertaking; (c) The underlying obligation has undoubtedly been fulfilled to the satisfaction of the beneficiary; (d) Fulfilment of the underlying obligation has clearly been prevented by wilful misconduct of the beneficiary; (e) or In the case of a demand under a counter-guarantee, the beneficiary of the counter-guarantee has made payment in bad faith as guarantor/issuer of the undertaking to which the counter-guarantee relates".

Further, paragraph (3) of the same article provides that: "in the circumstances set out in subparagraphs (a), (b) and (c) of paragraph 1 of this article, the principal/applicant is entitled to provisional court measures in accordance with article 20." Scholars consider article 19 of convention successful in achieving its political and technical objectives.

Article 20 continues with providing possibilities for court action under the title of "Provisional court measures":

"1. Where, on an application by the principal/applicant or the instructing party, it is shown that there is a high probability that, with regard to a demand made, or expected to be made, by the beneficiary, one of the circumstances referred to in subparagraphs (a), (b) and (c) of paragraph I of article 19 is present, the court, on the basis of immediately available strong evidence, may: a. Issue a provisional order to the effect that the beneficiary does not receive payment, including an order that the guarantor/issuer hold the amount of the undertaking, or b. Issue a provisional court order to the effect that the proceeds of the undertaking paid to the beneficiary are blocked, taking into 
account whether in the absence of such an order the principal/applicant would be likely to suffer serious harm.

2. The court, when issuing a provisional order referred to in paragraph 1 of this article, may require the person applying therefor to furnish such form of security as the court deems appropriate.

3. The court may not issue a provisional order of the kind referred to in paragraph 1 of this article based on any objection to payment other than those referred to in subparagraphs (a), (b) and (c) of paragraph 1 of article 19, or use of the undertaking for a criminal purpose."

From technical point of view, the Convention is successful in addressing major aspects of fraud rule developed by national courts in addition to offering a precise and useful guidelines. Article 19 (1) lists types of misconduct by beneficiary which result in application of fraud rule both under LC contract and underlying sales contract. Also Convention provides guidance for actions which victim of fraud can take by either withholding payment or refusing to honour presentation (bank) and applying for injunction remedy at court (applicant) in order to prevent issuing bank from honouring fraudulent presentation. Gao and Buckley consider fraud related provisions in UNCITRAL Convention as vital and positive development which can be used as a guide for national courts while applying the fraud rule.

There are two main criticisms to UNCITRAL Convention articles on fraud. On one hand, scholars criticize vagueness of provisions which might create problem in practice of independent undertakings. On the other hand, other scholars express concern on possibility for different court interpretations as a result of applying Convention's provisions which might increase the risk for international trade. In conclusion, UNCITRAL Convention has provided a constructive development in international application of LC fraud rule despite existence of different interpretations among national courts.

\section{CONCLUSION}

Documentary letters of credit are among most popular instruments used by traders and banks in the field of international trade finance. Despite their facilitating nature in smoothing up the process of international transactions, their mere documentary nature makes them vulnerable to the problem of fraud. Situation will become more complicated as the United States of America is the only country which has statutory regulations to regulate fraud in LC operation. England is following fragmented approach based on case law and other countries do not really have significant regulations in above mentioned area. Current paper tried to analyse the problem of fraud as a globally accepted exception to the principle of autonomy in documentary letters of credit by scrutinizing national legal systems in England and the USA as well as international legal framework applicable to LC operation which have been introduced by ICC and UNCITRAL.

Despite the fact that UCC and English law cover the fraud exception to an extensive level, ICC regulations show no trace of paying attention to such important problem. Among internationally accepted norms, Only UNCITRAL Convention provides provisions on how to deal with fraud in LC operations. This is clearly not sufficient as majority of LC users and active traders in international business have no detailed knowledge of American and English legal system. On the other hand, UNCITRAL Convention is only ratified by nominal number of countries which limits its application extensively. It is recommended to include fraud exception in ICC rules particularly UCP due to its 
extensive use as applicable law in process of LC Operation. On one hand inclusion of fraud rule in UCP will increase the clarity and expectably of LC operation and on the other hand it will reduce current existing problems of judges who are not familiar with detailed operation of documentary credits and bankers who have no legal expertise on how to deal with legal aspects of LC fraud in national legal systems.

\section{Bibliography:}

ALAVI, H.: Autonomy Principle and Fraud Exception in Documentary Letters of Credit, a Comparative Study between United States and England. In: International and Comparative Law Review, 2015, 15, 2.

ALAVI, H.: Documentary Letters of Credit, Legal Nature and Sources of Law. In: Journal of legal studies, 2016, 17, 31, pp. 106-121.

ALAVI, H.: Illegality as an Exception to Principle of Autonomy in Documentary Letters of Credit; A Comparative Approach. In: Korea University Law Review, 2016, 20, pp. 3-23.

ARKINS, J.R.C.: Snow White V. Frost White: The New Cold War In Banking Law. In: Journal of International Banking Law, J.I.B.L., 2000, 15, 2, pp. 30-41.

BARANAELLO, J.: Understanding the URDG 758. Available at: http://www.fpsc.com/DB/TreasuryPulse/ Fall2010/ Article4.html

BARENS, J. G. - BYRNE, J. E.: Letters of Credit. In: BYRNES, J. E. - BYRNES, Ch. S. (Eds.): Annual Survey of Letter of Credit Law and Practice. Montgomery Village, MD: The Institute of International Banking Law \& Practice, Inc., 2007.

BARENS, J. G. - BYRNE, J. E.: Letters of Credit: 2000. In: Business Law, 2001, 56, 4. Reprinted in: Annual Survey of Letter of Credit Law \& Practice, 2002, 13, 18.

BARSKI, K. A.: Letters of Credit: A Comparison of Article 5 of the Uniform Commercial Code and the Uniform Customs and Practice for Documentary Credits. In: Loy. L. Rev., 1996, 41, pp. 735-751.

BERTRAMS, R.: Bank Guarantees in International Trade. 3d. ed. The Hague: Kluwer Law International, 2004.

BUCKLEY, R. P.: The 1993 Revision of the Uniform Customs and Practice for Documentary Credits. In: Journal of Banking \& Finance Law \& Practice, 1995, 77.

BUCKLEY, R.P. - GAO, X.: Comparative Analysis of the Standard of Fraud Required under the Fraud Rule in Letter of Credit Law. In: Duke J. Comp. \& Int'l L., 2003, 13.

BUCKLEY, R.P. - GAO, X.: Comparative Analysis of the Standard of Fraud Required under the Fraud Rule in Letter of Credit Law. In: Duke J. Comp. \& Int'l L., 2003, 13.

BUCKLEY, R.P. - GAO, X.: The Development of the Fraud Rule in Letter of Credit Law: The Journey so Far and the Road Ahead. In: University of Pennsylvania Journal of Economic Law, 2002, 23.

BUCKLEY, R.P. - GAO, X.: The Development of the Fraud Rule in Letter of Credit Law: The Journey so Far and the Road Ahead. In: University of Pennsylvania Journal of Economic Law, 2002, 23.

BYRNE, J. E.: Preface. In: BYRNE, J. E. et al.: International Standbypractices ISP98 6. Paris: ICC Publishing, 1998.

D'ARCY, L.: Schmitthoff's Export Trade - The law and Practice of International Trade. 10th ed, London: Sweet \& Maxwell, 2000.

DOLAN, J. F.: Commentary on Legislative Developments in Letter of Credit Law: An Interim Report. In: Banking \& Fin. L. Rev., 8, 2002, 53.

DOLAN, J. F.: The Law of Letters of Credit: Commercial and Standby Credits. Rev. Ed. Boston: Warren, Gorham \& Lamont, 1996.

ELLINGER, P. - NOE, D.: The Law and Practice of Documentary Letters of Credit. Oxford : Hart Publishing, 2010.

ENONCHONG, N.: The Autonomy Principle of Letters of Credit: An Illegality Exception? In: Lloyd's Maritime and Commercial Law Quarterly, 2006. 
ENONCHONG, N.: The independence principle of letters of credit and demand guarantees. Oxford: Oxford University Press, 2011.

FLETCHER, G. P. - SHEPPARD, S.: American Law in a Global Context: The Basics. Oxford; New York: Oxford University Press, 2005.

GAO, X.: The fraud rule in the law of letters of credit: a comparative study. Vol. 2. The Hague: Kluwer law international, 2002.

GARCIA, R.L.F.: Autonomy principle of the letter of credit. In: Mexican Law Review, 2009.

GOODE, R.: Abstract Payment Undertakings and the Rules of the International Chamber of Commerce. In: Saint Louis University Law Journal, 1995, 39.

Int'l Chamber of Commerce, ICC Publication No. 205-207. Paris: ICC, 1998.

KATZ, R.: Report delivered at the I.C.C. Hong Kong meeting. Reprinted in: Int'l Chamber of Commerce, ICC Publication No. 470/893. Paris: ICC, 1999.

KELLY-LOUW, M.: Selective legal aspects of bank demand guarantees (Doctoral dissertation). Pretoria: University of South Africa, 2009.

KOZLCHYK, B., Letters of Credit. In: Int'l Encyclopaedia of Comparative Law, 1979, 10.

KUO-ELLEN, L. S.: UCP Needs to Change. In: Journal of Money Laundering Control, 2002, 5, 3.

KURKETLA, M.: Letters of Credit Under International Trade Law: UCC, UCP and Law Merchant. New York, London \& Rome: Oceana Publications. Inc., 1985.

LEAKOCK, S. J.: Fraud in International Transaction: Enjoining Payment of Letters of credit in International Transactions. In: Vand. J. Transnat'l L., 885,1984 (Fall), 17.

MALEK, A. - QUEST, D.: Documentary Credits - The Law and Practice of Documentary Credits Including Standby Credits and Demand Guarantees. 4th Ed. Haywards Heath, West Sussex: Tottel, 2009.

MOONEY, J. L. - BLODGETT, M. S.: Letters of Credit in the Global Economy: Implications for International Trade. In: Journal of International Accounting, Auditing and Taxation, 1995, 4, 2.

ROWE, M.: Do We Need a Transnational Law on Documentary Credits? Michael Rowe \& Bernard Wheble Debate. In: DCI (ICC), 1998, Spring, 4, 2.

TURNER, P.S.: New Rules for Standby Letters of Credit: The International Standby Practices. In: Banking \& Finance Law Review, 1999, 14.

United Nations Convention on Independent Guarantees and Stand-by Letters of Credit art. 5, Dec. 11, 1995, A/ RES/50/48. Available at http://www.uncitral.org/pdf/english/texts/ payments/guarantees/guarantees.pdf

WUNNIKE, B. - WUNNICKE, Diane B.: Standby and Commercial Letters of Credit. 2nd ed, New York: Wiley Law Publications, 1996.

ZHANG, Y.: Approaches to Resolving the International Documentary Letters of Credit Fraud Issue. Doctoral Dissertation. Joensuu: University of Eastern Finland, 2011.

\section{Contact information:}

Hamed Alavi, MBA, LLM, PhD Candidate

hamed.alavi@ttu.ee

Tallinn School of Law

Tallinn University of Technology

Estonia

Faculty of Law

Universitat Autònoma de Barcelona

Spain 